\title{
Evaluation of anti-lipase activity of leaf and bark extracts from Aquilaria subintegra and $A$. malaccensis
}

\author{
Mastura IBRAHIM ${ }^{1^{*}}$, Saripah Salbiah SYED ABDUL AZZIZ ${ }^{*}$, Chee Fah WONG ${ }^{2 *}$, Wan Nor Izzati WAN MOHAMAD DIN ${ }^{1}$, \\ Wan Rusmawati WAN MAHAMOD ${ }^{1}$, Yuhanis Mhd BAKRI ${ }^{1}$, Mohamad Syahrizal AHMAD ${ }^{1}$, Rozita YAHAYA ${ }^{1}$, Nor Hadiani \\ ISMAIL $^{3}$, Wan Mohd Nuzul Hakimi Wan SALLEH ${ }^{1}$ \\ Department of Chemistry, Faculty of Science and Mathematics, Universiti Pendidikan Sultan Idris, 35900 Tanjong Malim, Perak, Malaysia \\ Department of Biology, Faculty of Science and Mathematics, Universiti Pendidikan Sultan Idris, 35900 Tanjung Malim, Perak, Malaysia \\ Faculty of Pharmacy, Universiti Teknologi MARA, Puncak Alam Campus, 42300 Bandar Puncak Alam, Selangor, Malaysia
}

\begin{abstract}
Obesity is one of the serious health condition in the world and contributes to many chronic illnesses augmenting to high risk of death rate. With the purpose of obesity treatment, natural sources come to be significant to replace commercial drugs due to their harmful effect to the body. Therefore, a lot of studies were conducted on natural sources due to their potential as medicinal herbs. Aquilaria sp. plants are well known in traditional medicine as a sedative, analgesic and digestive. Even though there were no reports on applications of Aquilaria sp. towards obesity treatment, this plant has traditionally been used as laxative for weight reducing. In this study, the anti-lipase activity of an extract of barks and leaves from A. subintegra and A. malaccensis were investigated. The anti-lipase activity was measured by colorimetric assay on pancreatic lipase activity using porcine pancreatic lipase (PPL; triacylglycerol lipase, EC 3.1.1.3). The result indicated that among these two species of Aquilaria, A. malaccensis bark in dichloromethane crude showed high anti-lipase activity. Thus, these results suggest that Aquilaria sp. plant extracts might be of therapeutic interest with respect to the treatment.
\end{abstract}

KEYWORDS: A. subintegra; A. malaccensis; anti-lipase ; pancreatic lipase

\section{INTRODUCTION}

Obesity is a severe health condition that is encountered by a lot of people today. It is an epidemic problem and contributes to many chronic illnesses augmenting to the high death rate. In order of obesity treatment, dietary fat stimulates body fat storage more operative than dietary carbohydrate [1-2]. The key of dietary fat inhibits pancreatic lipase, the main enzyme which is hydrolysed $50-70 \%$ of dietary triacylglycerols into monoacylglycerols and free fatty acid (FFA); hence, the result could decrease absorption of fat, and thus energy uptake, which plays an important role in mediating obesity problem [3-4]. Therefore, in this study porcine pancreatic lipase (PPL; triacylglycerol lipase, EC 3.1.1.3) has been used as an enzyme. There are two common anti-obesity drugs available in the market, orlistat and sibutramine; orlistat blocks the producing of FFA and glycerides in gastrointestinal enzyme lipase and sibutramine acted as a monamine-reuptake inhibitor to surge satiety [5-6]. Unfortunately, the synthetic drugs caused the harmful effect for the long term [7]. To date, herbal products and dietary supplements are widely available in the market as an alternative way to replace the use of synthetic drugs. Many researchers focused on natural

Received: 30.05.2017 / Accepted: 15.09.2017

Corresponding Author: Saripah Salbiah Syed Abdul Azziz, Chee Fah Wong

E-mail: saripah@fsmt.upsi.edu.my, cheefah@fsmt.upsi.edu.my

Phone: +6015 - 48797313,+6015 - 48797326

ORCID No: 0000-0002-8499-3745, 0000-0003-1114-7000 sources, including plants, fruits and herbs as biological inhibitors. There are numerous studies of pharmacological properties of Aquilaria sp. which are currently explored for health therapy. Hence, this study will explore Aquilaria sp. to reveal the possible natural inhibitors.

A. subintegra and A. malaccensis belongs to the genus Aquilaria and in the family Thymelaeaceae. They are widely distributed especially in Asia due to its highest value of resin-impregnated heartwood. Aquilaria sp. also has been used traditionally as sedative, analgesic and digestive treatment [8]. Previous phytochemical studies of this genus showed the presence of terpenoids, phenolic compounds, flavonoids and sterols that contribute to its biological activities [9]. The leaves of Aquilaria sp. are believed to have major polyphenolic compounds which can be used as herbal tea and showed a laxative [10-12], anti-bacterial [13], and anti-diabetic properties [7]. In addition, stem of A. subintegra has been reported as promising in Alzheimer therapy [14]. As far as authors are concern, no publication was found on Aquilaria sp. as an anti-lipase agent. Therefore, through this publication it is hopeful that we reveal antilipase potential of Aquilaria sp. and subsequently isolate

How to cite this article: Ibrahim M, Syed Abdul Azziz SS, Wong CF, Wan Mohamad Din WNI, Wan Mahamod WR, Bakri YM, Ahmad MS, Yahaya R, Ismail $\mathrm{NH}$, Salleh WMNHW. Evaluation of anti-lipase activity of leaf and bark extracts from Aquilaria subintegra and A. malaccensis. Marmara Pharm J. 2018; 22 (1): 91-95 
chemical compounds especially polyphenolic groups and understand inhibitory mechanism towards lipase, an enzyme responsible for lipid breakdown.

\section{RESULTS AND DISCUSSION}

\subsection{Phytochemical screening of leaf and bark extracts}

Preliminary phytochemical screening of all crude extracts of these two species of Aquilaria barks and leaves showed the presence of flavonoid, steroid and terpenoid. The biological properties of plants extract are multiplex. Thus, the antilipase effect may be credited to the complex pharmacological action of phytoconstituents existing in the crude extract. Adnyana and colleagues (2014) suggested that the chemical components such as flavonoids, saponin, tannin, steroid and triterpenoid able to inhibit pancreatic lipase activity.

\subsection{Anti-lipase effect of Aquilaria crude extracts}

Twelve crude extracts from A. subintegra and A. malaccensis were investigated for their inhibition activities at concentration $100 \mu \mathrm{g} / \mathrm{mL}$. The inhibitory activities toward porcine pancreatic lipase are shown in Table 1. The value of lipase activity (positive control) was $0.753 \mathrm{U} / \mathrm{mL} \pm 0.037$. The result indicated that almost all crude extracts had a potential to inhibit PPL from producing free fatty acid by comparing value of positive control. Among those examined the DCM crude from A. malaccensis bark (AMB) showed the highest possibility to inhibit PPL activity with $91 \%$ reduction. This is probably because the crude extracts might contain polyphenolic compounds, which may include more active compounds. It's known that polyphenolic possess several biological activities. Previous study showed that polyphenolic compounds from molokheiya leaves play a role in reducing diet-induced obesity and oxidative stress [17]. In fact, the polyphenols which comprise flavonoids group, able to prevent obesity by inhibit enzyme deal with fat absorption [18].

Table 1. Effect of Aquilaria crude extracts toward pancreatic lipase activity.

\begin{tabular}{|c|c|c|c|}
\hline Plant Species & Plant Part & Crude Extract & Activity $\mathrm{U} / \mathrm{mL}$ \\
\hline \multirow{7}{*}{ A. subintegra } & \multirow{3}{*}{$\begin{array}{l}\text { Bark } \\
\text { Bark } \\
\text { Bark }\end{array}$} & Hexane & $0.580 \pm 0.086$ \\
\hline & & Dichloromethane & $0.462 \pm 0.052$ \\
\hline & & Methanol & $0.397 \pm 0.004$ \\
\hline & \multirow{4}{*}{$\begin{array}{l}\text { Leaf } \\
\text { Leaf } \\
\text { Leaf }\end{array}$} & Hexane & $0.348 \pm 0.077$ \\
\hline & & Dishonthon & $0510+0010$ \\
\hline & & & $0.548 \pm 0.040$ \\
\hline & & Methanol & $0.714 \pm 0.051$ \\
\hline \multirow{7}{*}{ A. malaccensis } & \multirow{3}{*}{$\begin{array}{l}\text { Bark } \\
\text { Bark } \\
\text { Bark }\end{array}$} & Hexane & $0.507 \pm 0.144$ \\
\hline & & Dichloromethane & $0.065 \pm 0.147$ \\
\hline & & Methanol & $0.727 \pm 0.131$ \\
\hline & \multirow{4}{*}{$\begin{array}{l}\text { Leaf } \\
\text { Leaf } \\
\text { Leaf }\end{array}$} & Hexane & $0265+0.061$ \\
\hline & & Hexane & $0.265 \pm 0.061$ \\
\hline & & Dichloromethane & $0.089 \pm 0.056$ \\
\hline & & Methanol & $0.231 \pm 0.078$ \\
\hline
\end{tabular}

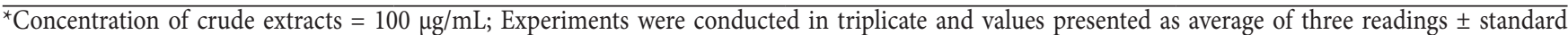
deviation.

The lipase activity was determined by observing development of color of fatty acid in solvent phase [15]; the more color develop, the activity of lipase is higher, while the activity of lipase is lower when the color is more colorless. Figure 1 shows the mean of lipase activity $(\mathrm{U} / \mathrm{mL})$ between two species $(n=3)$. From the graph showed that DCM crude of $\mathrm{AMB}$ had highest inhibition of lipase activity compared to the others. Its color also becomes colorless, suggesting that activity lipase was prevented. While looking at plant species, $A$. malaccensis was more counteract the enzyme activity than $A$. subintegra; which mean the A. malaccensis probably contain more active compounds compared to $A$. subintegra. This is supported with previous studies indicated that methanol extract of $A$. malaccensis leaves had highest antioxidant properties which is helpful to protect formation free radical and delay the existence of lipid peroxidation [19]. 


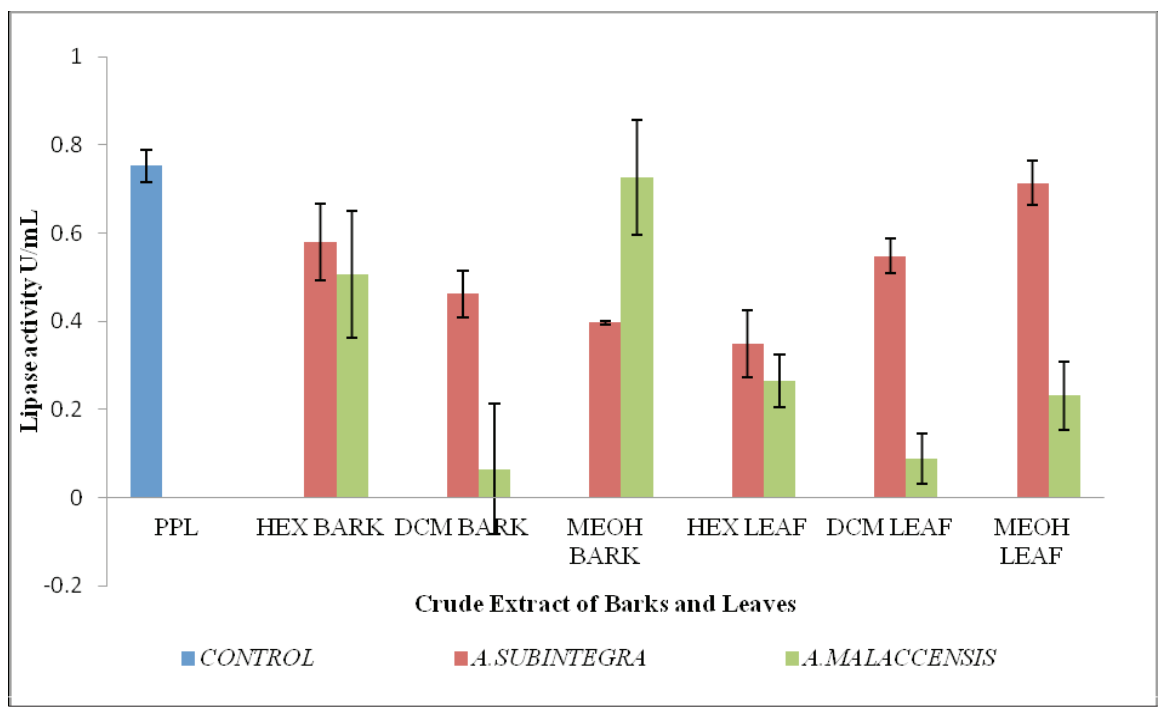

${ }^{\star}$ Concentration of crude extracts $=100 \mu \mathrm{g} / \mathrm{mL}$; Experiments were conducted in triplicate and values presented as average of three readings \pm standard deviation.

Figure 1. The mean of lipase activity $(\mathrm{U} / \mathrm{mL})$ of twelve crude extracts from Aquilaria species and PPL (positive control). Results are stated as mean $\pm \mathrm{SD}(\mathrm{n}=3),{ }^{*} \mathrm{p}<0.01$

The statistical analysis paired t-test by SPSS was conducted towards all crude extracts of Aquilaria species with significant different ${ }^{\star} p<0.01$. This study suggested that both Aquilaria sp. are worthy in their biological properties as well as DCM crude of AMB have a good promising to inhibit lipase activity. This hypothesis has been warranted with previous study indicated that Aquilaria species have pharmacological effect including in Alzheimer disease, diabetes mellitus and antioxidant [14]. This is followed by discovering laxative properties in Aquilaria leaves which believe contain active polyphenolic compound such as mangiferin and genkwanin 5 -O- $\beta$-primeveroside $[10,20]$. Aligned with this, the antilipase activity of Aquilaria crude extracts is possibly related with existence of polyphenolic compounds.

\section{CONCLUSION}

In this study, we screened twelve crudes from A. subintegra and $A$. malaccensis and found that AMB from DCM crude have a high potential to inhibit in-vitro lipase activity. This findings support further research to investigate the mechanism of isolated compound from the crude for better understanding as a potential inhibitor for obesity treatment.

\section{MATERIALS AND METHODS}

\subsection{Plant materials}

The leaves and barks of A. subintegra and A. malaccensis were collected from Kajang, Selangor, Malaysia in July 2014. A voucher specimen was deposited at the herbarium of Universiti Pendidikan Sultan Idris (Voucher No: AMWNI-M6002/1).

\subsection{Preparation of extract}

The barks and leaves were dried at room temperature, cut into small slices and powdered using a dry grinder. Dried barks and leaves were extracted via maceration technique, three times with hexane, dichloromethane (DCM) and methanol, $72 \mathrm{~h}$ for each time, respectively. The supernatant was filtered using Whatman No. 1 filter paper. Then, the residues were concentrated at $40^{\circ} \mathrm{C}$ using rotary evaporator. All crude extracts were stored at $4^{\circ} \mathrm{C}$ until used.

\subsection{Phytochemical screening}

All of twelve crudes of these two Aquilaria species were tested with $p$-anisaldehyde to screen the presence of several active group compounds such as terpenoid, steroid and polyphenolic including flavonoid compounds.

\subsection{Assay of lipase activity}

In vitro pancreatic lipase activity was determined by measuring the release rate of oleic acid (free fatty acid) from the standard curve of free fatty acid. Porcine pancreatic lipase (PPL) dissolved in buffer was induced as positive control (A), while crude extracts of Aquilaria as negative control (B), were dissolved in dimethyl sulfoxide (DMSO). This method was performed colorimetrically with slightly modification from Kwon and Rhee's (1986) method. $1.0 \mathrm{ml}$ of culture filtrate 
was mixed with $2.5 \mathrm{ml}$ of natural substrate (olive oil mixed with buffer, $1: 1, \mathrm{v} / \mathrm{v}$ ) and $20 \mu \mathrm{l}$ of $20 \mathrm{mM} \mathrm{CaCl}_{2}$. The substrate was prepared by mixing olive oil (Bertoli, Italy) and $50 \mathrm{mM}$ phosphate buffer equally. The same procedure was prepared onto $1.0 \mathrm{ml}(\mathrm{A})$ and $1.0 \mathrm{ml}$ of (B) filtrate, by mixing with $2.5 \mathrm{ml}$ natural substrate and $20 \mu \mathrm{l}$ of $20 \mathrm{mM} \mathrm{CaCl}_{2}$ respectively The mixture was shaken $30 \mathrm{~min}$ in water bath shaker at an agitation rate of $200 \mathrm{rpm}$. Then $1 \mathrm{ml}$ of $6 \mathrm{~N} \mathrm{HCl}$ was added to terminate the reaction of emulsion system and followed by adding $5 \mathrm{ml}$ of isooctane and mixing for $30 \mathrm{sec}$ using a vortex mixer. The upper isooctane layer containing the fatty acid was drawn off to a test tube and added $1 \mathrm{ml}$ of copper reagent before analysis. Lipase activity was determined by measuring the amount of free fatty acids released from the standard curves of free fatty acid; one unit of lipase activity was defined as $1 \mu$ mole of fatty acid releasing by enzyme in $1 \mathrm{~min}$ [15-16].

\subsection{Statistical analysis}

The results obtained were analyzed using paired test in Statistical Package for the Social Sciences (SPSS) version 20. The value of $p<0.01$ was considered to be statically significant.

\section{Acknowledgements}

The authors would like to thank Universiti Pendidikan Sultan Idris for providing laboratory facilities and financial support by FRGS Grant (2014-0030-101-02) from the Ministry of Higher Education (MOHE). Many thanks to Sayangku Nor Ariati Bt Mohamad Aris (Universiti Putra Malaysia) and Dr. Mai Shihah Bt Abdullah (Universiti Pendidikan Sultan Idris) who have contributed to works in this article.

\section{Authorship contributions}

Concept-S.S.S.A.A., C.F.W.; Design - M.I., S.S.S.A.A., C.F.W., W.N.I.W.M.D.; Supervision - S.S.S.A.A., C.F.W.; Resource - S.S.S.A.A., C.F.W., W.R.W.M.; Materials - S.S.S.A.A., C.F.W.; Data Collection and/or Processing - M.I., S.S.S.A.A., C.F.W., W.N.I.W.M.D.; Analysis and/or Interpretation M.I., S.S.S.A.A., C.F.W.; Literature Search - M.I., S.S.S.A.A., C.F.W., Y.M.B., S.A., R.Y., N.H.I., W.M.N.H.W.S.; Writing, Critical Reviews - M.I., S.S.S.A.A., C.F.W., W.N.I.W.M.D., W.R.W.M., Y.M.B., S.A., R.Y., N.H.I., W.M.N.H.W.S.

\section{Conflict of interest}

The authors declared no conflict of interest.

\section{REFERENCES}

[1] Adnyana IK, Sukandar EY, Yuniarto ARI, Finna S. Antiobesity effect of the pomegranate leaves ethanol extract (Punicagranatum L.) In high-fat diet induced mice. Int J Pharmacy Pharm Sci. 2014; 6 (4): 4-9.

[2] Kazmi I, Afzal M, Rahman S, Iqbal M, Imam F, Anwar F. Antiobesity potential of ursolic acid stearoyl glucoside by inhibiting pancreatic lipase. Euro J Pharmacol. 2013; 709 (13): $28-36$.

[3] Sergent T, Vanderstraeten J, Winand J, Beguin P, Schneider Y. Phenolic compounds and plant extracts as potential natural anti-obesity substances. Food Chem. 2012; 135: 68-73.

[4] Yun JW. Phytochemistry Possible anti-obesity therapeutics from nature-A review. Phytochemistry 2010; 71 (14-15): 1625-1641.

[5] Nicolás-vázquez I, Hinojosa J, Cruz J, Miranda R, Aceveshernández JM. Orlistat interaction with sibutramine and carnitine . A physicochemical and theoretical study. J Mol Struct. 2014; 1062: 1-12.

[6] Padwal RS, Majumdar SR. Drug treatments for obesity: orlistat, sibutramine, and rimonabant. Lancet. 2007; 369: 7177.

[7] Yunus S, Md Zaki NA, Ku Hamid KH. Microwave drying characteristics and antidiabetic properties of Aquilaria subintegra and Aquilaria malaccensis leaves. Adv Mat Res. 2015; 1113: 352-357.

[8] Hashim YZHY, Phirdaous A, Azura A. Screening of anticancer activity from agarwood essential oil. Phcog Res. 2014; 6 (3): 191-194.

[9] Noor N, Nik A, Adila N, Omar M, Ibrahim NA. In vitro antioxidant activity and phytochemical screening of Aquilaria malaccensis leaf extracts. J Chem Pharm Res. 2014; 6 (12): 688-693.

[10] Ito T, Kakino M, Tazawa S, Watarai T, Oyama M, Maruyama H, Araki Y, Hara H, Iinuma M. Quantification of polyphenols and pharmacological analysis of water and ethanol-based extracts of cultivated agarwood leaves. J Nutr Sci Vitaminol 2012; 58: 136-142.

[11] Ito T, Kakino M, Tazawa S, Oyama M, Maruyama H, Araki $\mathrm{Y}$, Hara $\mathrm{H}$, Inuma M. Identification of phenolic compounds in Aquilaria crassna leaves via Liquid ChromatographyElectrospray Ionization Mass Spectroscopy. J Food Sci Technol. 2012; 18 (2): 259-262.

[12] Kakino M, Tazawa S, Maruyama H, Tsuruma K, Araki Y, Shimazawa M, Hara H. Laxative effects of agarwood on lowfiber diet-induced constipation in rats. BMC Complement Altern Med. 2010; 10 (1): 68.

[13] Kamonwannasit S, Nantapong N, Kumkrai P, Luecha P, Kupittayanant S. Antibacterial activity of Aquilaria crassna leaf extract against Staphylococcus epidermidis by disruption of cell wall. Annal Clin Microb Antimicrob 2013; 12 (1): 1 . 
[14] Jok VA, Che Radzi N, Ku Hamid KH. A review: Pharmacological properties of Aquilaria spp. Adv Mat Res. 2015; 1113: 193-197.

[15] Kwon DY, Rhee JS. A simple and rapid colorimetric method for determination of free fatty acids for lipase assay. J Am Oil Chem Soc. 1986; 63 (1): 89-92.

[16] Leow TC, Rahman RNZRA, Basri M, Salleh AB. High level expression of thermostable lipase from Geobacillus sp. strain T1. Biosci Biotech Biochem. 2004; 68 (1): 96-103.

[17] Wang L, Yamasaki M, Katsube T, Sun X, Yamasaki Y, Shiwaku K. Antiobesity effect of polyphenolic compounds from molokheiya (Corchorus olitorius L.) leaves in LDL receptordeficient mice. Eur J Nutr 2011; 50 (2): 127-133.

[18] Garza AL, Milagro FI, Boque N, Campion J, Martinez JA. Natural inhibitors of pancreatic lipase as new players in obesity treatment. Planta Med. 2011; 773-785.

[19] Huda AWN, Munira MAS, Fitrya SD, Salmah M. Antioxidant activity of Aquilaria malaccensis (Thymelaeaceae) leaves. Phcog Res. 2009; 1 (5): 270-273.

[20] Hara H, Ise Y, Morimoto N, Shimazawa M, Ichihashi K, Ohyama M, Iinuma M. Laxative effect of Agarwood leaves and its mechanism. Biosci Biotech Biochem. 2008; 72 (2): 335-345. 